\title{
The simultaneous submission of a manuscript to more than one scientific publication: a legitimate strategy?
}

Authors of scientific articles often ask why they are unable to submit their manuscriptsto more than one journal at the same time.

For the authors, such a rule seems illogical given their urgent need to publish a certain number of articles each year. Faced with such an imperative, anything that expediates publication must seem desirable.

This argument appears less legitimate, however, when considered from a broader perspective that includes all those involved in the publication process. Copyright laws and the possible problems that such behavior can cause the researcher in the world of specialized publications should also be taken into account.

From their standpoint, authorscould submit the manuscript to several journals simultaneously, thus multiplying their chances of successful publication. However, what if their article is acceptedby more than one journal? Obviously, the authors could choose in which journal they prefer to be published and decline the offers from the others. Such an attitude, however, could create gaps in the editorial schedules of the rejected publications. The issue cannot therefore be considered solely from the perspective of the authors.

While acceptance by more than one journal at the same time suggests the production of a highly-regarded study, such an idea is a chimera. The editorial process of evaluating a manuscript involves a series of stages and people at each journal (editors, referees, reviewers), and each publication will have included the article and its attachments (illustrations, figures, images, tables, pictures, flowcharts...) in its editing schedule.

When the authors reject an offer of publicationfrom a scientific journal, the ethical compromise agreed upon during the consideration of the submission is violated, perhaps resulting in the journal beingunable to honor the pre-established schedule of its currentedition, as the editor will have to hastily replace the article with another at the same stage of evaluation.

It should also be emphasized that the theme of "ethics in research" is embodied in all scientific endeavors, as there is a need for rectitude to ensure the credibility of results and sincerity in the relationshipsbetween the different parties involved in the process. Every researcher is duty bound to respect the understandings upon which all scientific communication is based ${ }^{1}$.

There is also a range of other actions that can lead to both scientific misconduct and legal consequences ${ }^{2}$, about which reviewers and referees are often vigilant, such as theuse of the findings of others without approval; plagiarism; self-plagiarism; improper authorship; non-compliance with legislative and regulatory requirements; transgression of established research practices; simulacrum of data; inconsistency in the validation 
of the research; incompetence whenobjecting to unsuccessful validation trials; improper attitudes in the presumption of misconduct; and the inclusion of co-authors who did not actively participate in the study ${ }^{3}$.

As the severity of such fraudulent actions can vary, so the punishments for researchersdiffer depending on the infraction. In general, infringements that undermine the integrity of the research process are considered serious and can lead to severe penalties.

The consequences of academic misconduct can beextremely seriousfor a researcher's curriculum due to the harm they can cause the scientific world. The invalidation of an article can result in the loss of financial support from an institution or research fund. Moreover, depending on the type of fraud, the researcher may suffer legal consequences, further compromising the institution which he or she represents. The authors and co-authors of scientific works mustalso assume the professional, public, ethical and social responsibility of publication in accordance with Copyright $\mathrm{Law}^{2}$.

When deciding to submit an article to a journal, the authorsare granting part of the copyright of their work to the same (if the article is accepted), and so cannot make the same commitment to other publications. In addition, if simultaneous submission is discovered, the author in question will be scorned by the academic world, and will have little chance of future publication.

In 2006, in an editorial in Revista Quimica Nova (the New Journal of Chemistry) entitled "Competition, Success and Ethics in Science", Prof. Fernando Coelho (UNICAMPI), said that: "speedy publication of the results of a study should not always be our driving force; what should always matter is the accuracy and consistency of what we publish"4.

The exaggerated importancegranted to quantity of publications as the parameter of success of a researcher should be reconsidered, representing as it does the root of academic misconduct both in Brazil and other countries.

Tranquility, balance and serenity are therefore required, with authors always plotting a route towards the seas of academic honesty. If the goal is to increase the possibilities of publication, it is better to producemore articles and submit them to different periodicals. Now, let's get to work and good luck!

Luiz Antonio Costa Tarcitano

Editorial Assistant and Portuguese Reviewer for the Revista Brasileira de Geriatria e Gerontologia.

\section{REFERENCES}

1. Fanelli D. "How many scientists fabricate and falsify research?: A Systematic review and meta-analysis of survey data”. PloS ONE [Internet]. 2009 [acesso em 15 abr. 2018];4(5):1-11. Disponível em: http://journals.plos.org/plosone/ article?id=10.1371/journal.pone.0005738

2. Brasil. Lei n ${ }^{\circ} 9.610$, de 19 de fevereiro de 1998. Altera, atualiza e consolida a legislação sobre direitos autorais e dá outras providências. Diário Oficial [da] União. 20 fev. 1998. Seção 1. p. 3. Disponível em: http://www.planalto.gov. br/ccivil_03/leis/19610.htm

3. Brasil. Resolução Conselho Federal de Medicina no 1931/2009, aprova o Código de Ética Médica, anexo a esta Resolução, após sua revisão e atualização. Diário Oficial [da] União. 24 set. 2009. Seção 1. p. 90. Disponível em: http://www.rcem.cfm.org.br/index.php/cem-atual

4. Coelho F. Competição, sucesso e ética em ciência [Editorial]. Quím Nova [Internet]. 2006 [acesso em 23 abr. 2018];29(2):185. Disponível em: http://quimicanova.sbq.org.br/imagebank/pdf/Vol29No2_185_00-editoria29-2.pdf 